\title{
The Increase of Vietnam Military Capability in the South China Sea Dispute: Arms Race or Status Quo?
}

\author{
Putti Ananda Hiswi \\ Universitas Indonesia
}

\begin{abstract}
This paper analyzes Vietnam's decision to increase its military strength in facing China in the South China Sea. Most of the existing works on the topic studied emphasized the interest of both states and their intention to enhance military power to secure their claimed territory. However, the previous studies have not explained that the selection of Vietnam's policies to strengthen its military capabilities would impact the occurrence of arms races in the region or only a form of balancing of the opposing military forces. This research is applying qualitative research methods with data sourced from primary and secondary data from official documents, books, journals, online news. This article shows that Vietnam's policy to increasing military capability could perceive as a form of an arms race or a way of maintaining its military status quo with opponents.
\end{abstract}

Keywords: Vietnam; the South China Sea, military capabilities, arms races, arms dynamics

Tulisan ini menganalisis keputusan Vietnam untuk meningkatkan kekuatan militernya dalam menghadapi Tiongkok di Laut Cina Selatan. Penelitian terdahulu umumnya menunjukan kepentingan kedua negara dan niat mereka dalam meningkatkan kekuatan militer sebagai upaya mengamankan wilayah yang mereka klaim sebagai bagian dari teritori mereka. Namun, studi sebelumnya belum menjelaskan mengenai pemilihan kebijakan Vietnam untuk meningkatkan kemampuan militernya dapat menyebabkan dua kemungkinan yaitu terjadinya perlombaan senjata di wilayah tersebut atau hanya sebagai bentuk penyeimbangan kekuatan militer lawan. Penelitian ini menerapkan metode penelitian kualitatif dengan data yang bersumber dari data primer dan sekunder dari dokumen resmi, buku,jurnal, berita online. Tulisan ini menunjukkan bahwa kebijakan Vietnam untuk meningkatkan kemampuan militer dapat dianggap sebagai bentuk perlombaan senjata atau bentuk mempertahankan status quo militernya dengan lawan.

Kata-kata kunci: Vietnam; Laut Cina Selatan, kemampuan militer, perlombaan senjata, dinamika senjata 
The South China Sea dispute is a complex problem involving several countries in Southeast Asia, such as Vietnam, the Philippines, Malaysia, and Indonesia (Zhao 2018). The case happened to pose threats to the development of ASEAN countries' integration, particularly to Vietnam's national security, which shares national borders with China and risks future cooperative relations with China (The Maritime Executive 2018). China and Vietnam have a long history of conflict on land and sea, including border conflicts (The Maritime Executive 2018). In January 1974, a brief battle between Vietnamese and Chinese warships resulted in the loss of Vietnamese ownership in the Paracel Islands (Grossman 2018, 116). Another brief battle on the Spratly Islands in March 1988 resulted in the deaths of dozens of Vietnamese sailors on Johnson South Reef. China kept continuing its activities around disputed island areas, such as moving oil rigs into disputed waters (Grossman 2018, 116).

In 2013, Vietnam supported the Philippines because they felt that their Exclusive Economic Zone (EEZ) threatened by proposing a claim of China for the South China Sea to the International Arbitration Court, The Hague (BBC 2016a). The International Arbitration Court firmly stated that China has no legal basis, violates Philippines sovereign rights, and causes environmental damage by making artificial islands in the South China Sea (BBC 2016b). The legal victory for the Philippines has significance for other claimant countries. The International Arbitration decision confirmed that China has no legal basis under UNCLOS to claim the sharing of resources in the EEZ from ASEAN countries (Beckman 2016). Vietnam welcomed the verdict. After all, Vietnam would be entitled to EEZ and the continental shelf produced by its extensive coastline because Vietnam's coastline provided a full EEZ, which stretches 200 miles eastward to South China (Zhao 2018).

Nine dash line, decided by the International Arbitration Court, cannot be used as a basis for ownership of the South China Sea region by China. It turned China itself not to admit the decision made (Permanent Court of Arbitration 2016, 1-2). China continued to carry out its activities around the Spratly Islands and the Paracel Islands, a dispute between China, the Philippines, and Vietnam. Besides, warships are also deployed by China around disputed waters (RMOL 2011). The event caused strong reactions from several Southeast Asian countries by increasing spending on weapons and buying new frigates, tanks, helicopters, fighter jets, and submarines (Heiduk 2017). From 2011 to 2019, Vietnam kept conducting defense cooperation or increased military capability to face China in the South China Sea. In 2011, Vietnam added two Russian type 3.9 Gepard frigates (Heiduk 2017). In 2014, China confronted Vietnam by drilling for oil in disputed waters; Vietnam reacted by sending 29 ships (The Maritime Executive 2018). The Vietnamese encountered stiff resistance from Chinese vessels, which resulted in a Vietnamese fishing boat being hit and sunk by a Chinese ship (The Maritime Executive 2018). In 2016, Vietnam received assistance from Russia to improve its naval defense system and became a source of import for six submarines for Vietnam (Wezeman et al. 2018). Vietnam's weapons imports increased by almost 700 percent over the decade (Heiduk 2017). In 2018, Vietnam signed an agreement to purchase more than 1 billion USD in Russian submarines and aircraft (Jennings 2020). The rise in military cooperation and spending intended to anticipate threats from outside, such as China, in the case of the South China Sea. 
The prospect of a naval arms race in Southeast Asia can be seen from the South China Sea dispute. The countries in dispute with China have participated in demonstrating their maritime capabilities. The coastal states of the South China Sea have carried out massive military expenditures to increase their navy's strength, including in the field of aviation, maritime, mobile anti-ship missile systems, and maritime surveillance. China has aggressively pushed ASEAN countries involved in the South China Sea to increase defense budgets in the last ten years, particularly in the navy sector. The prospect of an arms race is interrelated with the broader context in which this change occurs along with the increasing strategic uncertainty over the rise of China and ASEAN countries (Heiduk 2018). Vietnam increased its military capabilities as anticipation or a reaction to the procurement of weapons from other countries. However, this increase in military power could be a potential arms race in the Southeast Asian region, which is something ASEAN has avoided since before. ASEAN, through the principles, set out in the 1976 Amity and Cooperation Agreement (TAC), states that the resolution of differences or disputes must be carried out in a peaceful manner (The ASEAN Secretariat 2016). Previous studies related to the increasing military power between Vietnam and China in the case of the South China Sea generally discuss three categories based on the point of view used, namely (1) Vietnam's interests, (2) China interests, and (3) potential arms races in the region. In the previous studies, many scholars saw how Vietnam claimed the whole area of the Paracel and Spratly regions (Hoang Sa and Truong Sa) and had spent many resources to modernize its navy and air force (Acharya 1988; Karp 1990; Thayer 1994; Tønnesson 2000).

The second category uses the viewpoint of China's interests in which China is increasing its military strength and mobilizing its troops in disputed waters to show China's firmness regarding its claim to the South China Sea region (Zhao 2018). The final category is using the perspective of the potential arms race. In conclusion, rather than considering the increase in the military power of countries in Southeast Asia as a race of arms, this study sees it as a form of maintaining the military status quo (Bitzinger 2010). This previous study saw an increase in the military capacity of Southeast Asian countries that were still in reasonable limits, which did not need to be indicated as a form of the arms race in the Southeast Asian Region.

All the previous studies show that both countries have interests and increase their military power to secure the territory that they consider as part of their territory. However, the previous studies have not explained the selection of Vietnam's policies to strengthen its military capabilities would have an impact on the occurrence of arms races in the region or only a form of balancing of the opposing military forces. With the consequence that Vietnam, which is an ASEAN member country, should only make efforts to resolve disputes in a peaceful manner rather than other forms of force used, such as the arms race. Based on the previous explanations, the writer proposes a research question from this paper, "Why does Vietnam choose the policies that could be leading to the arms race against China in the South China Sea?"

\section{Arms Dynamics: Theoretical Framework}

The author tried to analyze Vietnam's policy in increasing its military capabilities as a form of the arms race in facing China in the South China Sea. Vietnam has strengthened its defense capacity to deal with threats from China's claims or the South China Sea. 
However, this can trigger an arms race in the region and also clash with the values of ASEAN's peaceful resolution of conflicts. There are some possibilities to enhance the country's military capabilities. Firstly, these countries have an arms race. Secondly, increasing their defense capability is a form of maintaining the status quo and showing a form of arms dynamics.

The first approach used in this research is the theory of arms dynamics explained by Barry Buzan (Buzan 1987, 72). He refers to the entire set of pressure that constructs countries to acquire armed forces and change the quantity and quality of the armed forces (Buzan 1987, 73). The arms dynamics do not only refer to the global arms process but also to investigate the conditions of a particular country. The arms dynamics arise after the need to find a term that explains the standard conditions of military relations in an anarchic system since not all the standard conditions become a form of the arms race.

There are two possibilities in arms dynamics: (1) the arms race that occurs as the most extreme manifestations of arms dynamics, or (2) maintaining the military status quo (Buzan 1987, 73). The arms race happens when there is a pressure that leads the country to a big competition for the expansion of military power. In contrast, maintenance of the military status quo used to show the regular operation of arms dynamics. Maintenance of the military status quo and arms races can be used to describe one country's activities or the character of relations between two or more countries. The arms race and the maintenance of the military status quo, are extreme situations between countries. The situation can be explained by the maintenance of the military status quo, which can increase to an arms race. The arms race can be abated to maintain the military status quo (Buzan 1987, 72). Thus, the arms race and the maintenance of the military status quo are manifestations of the same arms dynamics, both of which have the same characteristics and differ only to some degree.

The idea of arms race shows that two or more countries are involved in a competition to gather military power against each other. It is the usual process for some countries to create armed forces and keep their equipment up to date (Buzan 1987, 72). The arms race shows that there is military competition among countries when their efforts to defend themselves militarily lead them to the increase of threat. In other words, given the political conditions of anarchy, countries are vulnerable to competition, and military technology is the primary independent variable. The arms race shows that military technology dynamics are mostly responsible as one of the main problems in relations between countries. All of these definitions show that the arms race is a very abnormal condition in relations between countries that reflects one or both active political competition, and fear one another's military potential (Buzan 1987, 73).

Buzan explained three models to understand better the dynamics of weapons: (1) the classical action-reaction model, which seeks the driving force of weapons dynamics in competitive relations amongst countries; (2) domestic structural models look for the driving forces of weapons dynamics in the state's internal economic, organizational, and political work; and (3) the imperative technological model, interpreting the dynamics of weapons in terms of general processes of progress in technology (Buzan $1987,73)$. In the first model, the classical action-reaction implicitly explains the dynamics of weapons driven by external factors. An action by the state to increase its military power will increase the level of threat seen by other countries and cause them to react by increasing their strength (Buzan 1987, 76). In the second model, the 
domestic structure focuses on the idea when the dynamics of weapons generated by encouragement from the state (Buzan 1987, 97). There is an assumption that each country in a position of long-term competition tends to adjust its internal structure to take into account competition as a problem in the future. Thus, the state tends to institutionalize its military capabilities by developing the institutionalization of military research and development (R\&D) (Buzan 1987, 96). The third model, technological imperative, shows that there is a technological leap, not only a form of the military but also a civil product (Buzan 1987, 105). The idea of a world military order contains elements of an imperative technological model in which the doctrines, models determine the dynamics of weapons as a global phenomenon, and all countries stuck in military patterns and standards throughout the world, and technologies of significant arms manufacturers (Buzan 1987, 108).

\section{The Three Models of Arms Dynamics of Vietnam}

In this section, the author tries to analyze the three models of arms dynamics of Vietnam in increasing military power against China in the case of the South China Sea. The analysis would explain the conditions behind Vietnam's policy from the arms dynamics concept. The author also tries to analyze the conditions that demonstrate the shape of the three models, which will explain how Vietnam decided to increase its military strength. The explanation will be justifying Vietnam's policy, increasing its military strength for an arms race with China, or it is only as a form of maintaining the military status quo and balancing power with their opponents.

\section{The Classic Actions in the Conflicts of Vietnam and China}

The basic proposition of the classic action-reaction model is explaining that states will strengthen their weapons because of external threats. In this case, the reason Vietnam decided to increase its military strength is China's move to the disputed area. Moreover, China's increase in defense budget was 10.7 percent in 2013, 12.2 percent in 2014, 10.1 percent in 2015, had decreased 7.6 percent in 2016, but again experienced an increase in the defense budget by 7.5 percent in 2019 (CNN 2019; Rajagopalan 2018). China announced its intention to conduct a previously planned military training with Russia in the South China Sea and sent strategic bombers flying over Scarborough Shoal to prevent other countries from taking further action (Zhao 2018). Chinese troops or the People's Liberal Army (PLA) have shown a series of new weapons for naval and air combat that available in the South China Sea. China also exposed its troops while handling DF-16 missiles, which could attack US military bases on Okinawa, and DF-21D, anti-ballistic missile killers with a range of $1,450 \mathrm{~km}$, and showed new H-6 bombers deployed to patrol the Scarborough Shoal (Zhao 2018).

The situation pushed Vietnam further. In 2015 Vietnam spent USD 4.5 billion on its armed forces; it shows an increase of almost 200\% since 2005, and the 2015 defense budget is equivalent to 2.3 percent of GDP (Heiduk 2017). Until the mid-200os, Vietnam still equips the ancient military equipment from Soviet stockpiles. However, with the background of increasing tensions with China in the South China Sea, Vietnam has made significant changes to its weapons policy (Heiduk 2017). Vietnam's military spending reached USD 5.0 billion in 2016 or 8 percent of total government spending (Vietnam Ministry of Defense 2017). In 2016 the Vietnam Navy's VPAN had acquired 
six kilo-class submarines made in Russia (Abuza \& Anh 2016). The acquisition causes Vietnam to be the most sophisticated submarine fleet in the region. Vietnam acquired two Gepard class frigates in 2011, the largest and most modern surface warship (Abuza \& Anh 2016). Vietnam acquired two Molniya missiles from Russia, which gave Vietnam the ability to target every facility built by China in the Spratly Islands or Paracel (Abuza \& Anh 2016). In 2018, Vietnam signed an agreement to purchase Russian ships and aircraft, which were worth 1 billion USD and planned to purchase weapons from the United States (Jennings 2020). In cooperation with India, Vietnam agreed on the implementation of the 2015-2020 Joint Vision Statement on Defense Cooperation in the same year. This joint vision statement intended to enhance cooperation in training human resources and promote collaboration between the Army, Air Force, Navy, and coast guard of the two countries (The Economic Times 2018).

In an anarchic international system, military competition between states can not be avoided, especially if the two countries have conflicting interests. As explained by the classic action-reaction model that the anarchic international system also encourages the state to increase its military power in response to threats from its opposing state. In this case, Vietnam and China have the same interests, namely the Spratly and Paracel Islands' overlapping claims based on their respective historical claims. When China increases its military power and places its navy in disputed waters shows that China is ready to fight if necessary. The situation has encouraged Vietnam to increase its military strength by increasing its country's military budget and renewing its military equipment.

The power increase by Vietnam could impact the occurrence of an arms race if defense spending increased and if the increase in military activity affected the other sectors of the national budget. From the data analysis, Vietnam's military budget has increased significantly since 2013. However, the defense budget increase does not cause sacrifices in other sectors in Vietnam's annual budget. It shows that Vietnam is making efforts to maintain the military's status quo, which can be seen from its military budget.

By analyzing through the classic action-reaction model, it can be seen that Vietnam's policy of increasing its military strength is a form of response to increasing the military strength of opponents who are at risk of increasing the threat level. Besides, Vietnam and China disputed the South China Sea case so that every military policy undertaken by China caused a perception of threats to Vietnam to emerge. Vietnam's reaction to this potential threat was to increase at least its military strength to face the opponent. However, the increase in military power based on the criteria of the classic actionreaction model did not lead Vietnam to an arms race with China. The increase in military power is more a form of maintaining the status quo of the military in the South China Sea.

\section{Domestic Structure Model in Vietnam Armament Dynamics}

This domestic structural model seeks to show that impulses from within the state generate the dynamics of weapons. Historically, Vietnam and China have a long history of conflict, which then always creates tension. The long history is one form of encouragement for Vietnam to develop its weapons dynamics based on the domestic structure model. Nevertheless, as a developing country, Vietnam has a low growth of the defense industry. Vietnam's weapon needs still obtained from Russia, Belarus, 
Ukraine, and Israel (Blanchfield et al. 2017). Throughout 2012 to 2016, Vietnam was the largest arms importer in the Southeast Asian region, which was previously Singapore's largest importer in the region (See Figure 1) (Blanchfield et al. 2017). The increase in Vietnam's arms imports is related to the escalating South China Sea conflict and an increase in China's military power.

Figure 1

Changes in Arms Imports by Countries in Southeast Asia

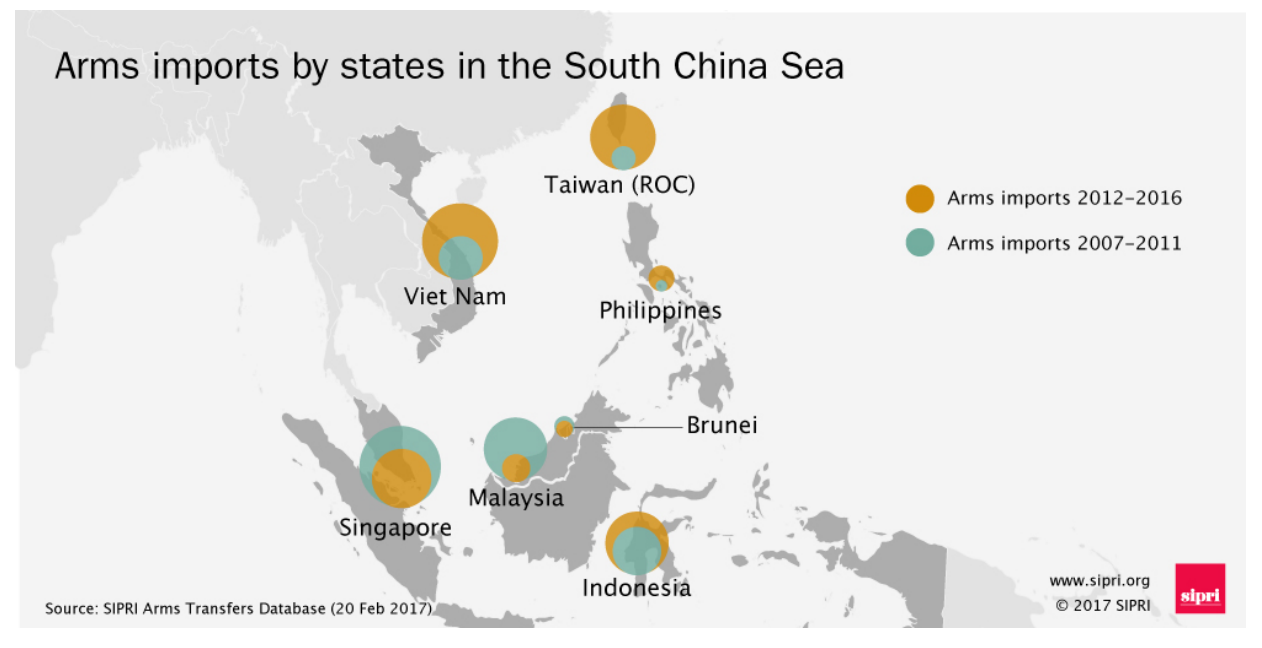

(Sources: Blanchfield et al., 2017)

In the R\&D aspect of the defense industry, Vietnam is still in the early process of development as the developing country's domestic structure described by Buzan. Vietnam conducts international cooperation in the national defense industry to meet the demands of the armed forces. Vietnam's national defense industry prioritizes international cooperation in technology research and transfer, production and repair of weapons equipment, and personnel (Global Security 2011). The Vietnamese defense industry's capability is mostly limited to small-scale shipbuilding (such as patrol and other additional ships), mostly based on foreign models (Bitzinger 2013). They also have a license in the production of Russian-designed missile systems, such as Yakhont anti-ship missiles and Igla missiles (Bitzinger 2013). The prolonged conflict is one of the threats, which becomes the pressure for Vietnam to develop its military industry and strive to become a producer of its own military needs. Vietnam's internal structure shows that the R\&D of the defense industry is still at an early stage. It could be explaining the reason why Vietnam is increasing its defense forces, as a form of maintaining the status quo rather than a form of an arms race. Vietnam's defense industry has not demonstrated its ability to achieve forms of arms races with China, which much more developed in terms of the defense industry.

Vietnam's internal structure shows its response to the advancement of military technology by importing weapons from a country that has a developing defense technology, such as Russia, regardless Vietnam cannot develop it is own the R\&D of the defense industry. Arms procurement through imports by Vietnam is a form of support for the domestic defense industry by completing the deficiencies of the domestic defense industry's ability. However, the attempt to do an arms race cannot sufficiently be indicated by the increase in the value of imports and military power. The increase of Vietnam's military power also considered as a form of maintaining the military status 
The Increase of Vietnam Military Capability in the South China Sea Dispute: Arms Race or Status Quo?

quo. Vietnam is trying to maintain the military status quo to maintain its capabilities, especially in the South China Sea dispute.

\section{Imperative Technological in the Development of Vietnamese Weapons}

The imperative technological model shows that there is a technological leap where technology is not only a form of military products but also a civilian product. In this case, instead of experiencing a technological leap, Vietnam has been going through the modernization of defense technology. Defense technology develops along with the development of civil technology. However, this did not make Vietnam experience a military technological leap because there was no significant technological change. Vietnam's military forces underwent modernization, but the process only improved the quality of weapons, not developing technology that gave rise to a military technological leap (Abuza \& Anh 2016).

Importing arms from countries that have more advanced technology had become the main activity carried out by Vietnam to provide its military needs. The increase in arms imports by Vietnam from 2012 to 2019 affected Vietnam's tenseness relations with China in the case of the South China Sea (Blanchfield et al., 2017; Jennings, 2020; The Economic Times, 2018). In this case, what Vietnam wants to achieve is not to produce technology that is superior to China but to try to have technology that can be used to face China in the confrontation of the South China Sea case. Instead of developing its defense industry, Vietnam tries to prioritize getting technology superior to Russia as the primary source of Vietnam's weapons imports (Strelávina 2016). The acquisition of six Russian-made submarine Kilo-class ships in 2016 by Vietnamese naval forces has shown a form of Vietnam's military modernization (Abuza \& Anh 2016). Vietnam has a high-tech submarine fleet among countries in the region due to the acquisition. Besides that, Vietnam also acquired two Gepard class frigates in 2011, which also showed a form of military modernization with the procurement of newer military equipment (Abuza \& Anh, 2016). However, this does not indicate a technological leap in the dynamics of Vietnam's weaponry.

Vietnam naval force strengths in 2018 consisted of 9 Frigates, 14 Corvettes, six submarines, 25 patrol vessels, eight mine warfare vessels, and along with 65 naval assets (Global Fire Power 2018). The majority of these naval assets are the outcome of imports and cooperation with Russia. Vietnam's domestic defense production capability is relatively undeveloped. Russia emerged as the largest supplier of military equipment to Vietnam with a 93\% share of Vietnam's imports, followed by Ukraine with 6\% and Romania and Israel, each with 1\% (Market Intelligence Report 2011). In 2010, Russia accounted for $98 \%$ of the country's defense imports, the leading equipment from Russia supplied to Vietnam consisted of surface battleships, submarines, and aircraft \% (Market Intelligence Report 2011).

The development of industries in the civil sector, which will encourage the defense sector, is the main argument of the imperative technological model, but this does not occur in the development of the Vietnam defense industry. Vietnam, in general, only modernizes its military. Not only that but Vietnam still also focuses on economic development rather than maximizing the defense budget. The element of the imperative technological model is Vietnam's pattern, and the standard of its military determined by the doctrines, models, and technology of the primary weapons producer, Russia. The 
imperative technological model owned by Vietnam indeed experienced a progression because of the state's perception that it cannot be sure that existing weapons will remain valid, thus raising fears if their opponents will gain military advantage by being the first to achieve technological breakthroughs. However, the limited ability of Vietnam to develop weapons; to import weapons from the country with the best technology to be able to outperform its opponents in the region.

From the analysis of the imperative technological model, the increasing strength carried out by Vietnam in dealing with China in the South China Sea dispute did not show a technological leap, which urged the development of the defense industry. Vietnam imported the technology from Russia, so all forms of doctrine, models, and technology follow Russia's developments. Hence, at this stage, Vietnam's increasing strength did not aim to lead to an arms race with China. Vietnam is trying to balance its military power so that the military status quo keeps maintained. The increase in Vietnam's military strength is a form of reaction to the perception of feeling threatened with Chinese military power, which had demonstrated around the disputed waters.

\section{Conclusion}

From the description above, this paper shows that the increase in Vietnam's military capability in dealing with China in the South China Sea can be analyzed using arms dynamics. It will explain the rise of a country's military power does not always lead to the arms race but can also lead to maintaining the military status quo. By using three models of arms dynamics analysis framework, it can be seen that the objectives of the policy of increasing Vietnam's military power directed towards maintaining the military status quo. Countries strengthen their weapons because of the threats is explained in the classic action-reaction model. In this case, the threat from China, which first strengthens and shows its military power in the disputed area, becomes the main reason for Vietnam to increase its military strength.

The second model, the domestic structure, shows that when a country gets encouragement, it can form the dynamic of weapons. In this case, Vietnam and China have a long history of conflict which eventually led to tension between them. Based on the domestic structure model, the long history becomes a push for Vietnam to develop its weapons dynamics. However, Vietnam cannot develop its R\&D of defense industry but provide the national armies' needs by importing it to be an accompaniment in Vietnam's domestic structure. Then, from the analysis of the third technological imperative model, it shows that Vietnamese weaponry's technological leap failed. Vietnam's technology is imported from Russia so that all forms of doctrine, models, and technology follow Russia's developments. The three models show the tendency of the rise of military power by Vietnam toward China in the South China Sea dispute case is a form of maintaining the military status quo. The rise of power was carried out as a reaction to China, as in Vietnam saw it as a threat. The rise of military capabilities that were done by Vietnam contributed less potential for an arms race in the Southeast Asian region since the dynamic capabilities of Vietnam's arms did not meet the criteria to do so. 
The Increase of Vietnam Military Capability in the South China Sea Dispute: Arms Race or Status Quo?

\section{References}

\section{Book \& Chapter in Book}

Buzan, Buzan. 1987. An Introduction to Strategic Studies. Palgrave Macmillan

\section{Journal and Online Journal}

Acharya, Acharya. 1988. "Arms Proliferation Issues in ASEAN: Towards a More “Conventional” Defence Posture?”, Contemporary Southeast Asia, 10 (3): 242268.

Beckman, Robert. 2016. "The South China Sea ruling: game changer in the maritime disputes”, RSIS Commentary, (180): 1-6.

Bitzinger, Richard A. 2010. "A New Arms Race? Explaining Recent Southeast Asian Military Acquisitions”, Contemporary Southeast Asia, 32 (1), 50-69.

Bitzinger, Richard. A. 2013. "Revisiting Armaments Production in Southeast Asia: New Dreams, Same Challenges", Contemporary Southeast Asia, 35 (3): 369

Grossman, Derek. 2018. "Can Vietnam's Military Stand Up to China in the South China Sea?”, Asia Policy, 13 (1).

Karp, Aaron. 1990. "Military Procurement and Regional Security in Southeast Asia", Contemporary Southeast Asia, 11 (4): 334-362.

Thayer, Carlyle. A. 1994. "Vietnam: Coping with China", Southeast Asian Affairs, 351367.

Tønnesson, Stein. 2000. "Vietnam's Objective in the South China Sea: National or Regional Security?”, Contemporary Southeast Asia, 22 (1): 199-220.

Zhao, Suisheng. 2018. "China and the South China Sea Arbitration: Geopolitics Versus International Law”, Journal of Contemporary China, 27 (109).

\section{Online Article}

Abuza, Zachary \& Anh, Nguyen N. 2016. "Vietnam's Military Modernization", The Diplomat, 28 October 2016 [online] https://thediplomat.com/2016/10/vietnamsmilitary-modernization/ [accessed at 14 March 2020].

BBC. 2016a. "Apa pengaruh putusan Mahkamah Arbitrase soal Laut China Selatan?” [online] http://www.bbc.com/indonesia/dunia/2016/07/160711_dunia_filipina_China_ mahkamah_preview [accessed at 12 March 2020].

BBC. 2016b. "China kembali tegaskan klaim atas wilayah di Laut China Selatan" [online] http://www.bbc.com/indonesia/dunia/2016/07/160712_dunia_reaksi_lautChinaselatan [accessed at 12 March 2020].

Blanchfield, K., Wezeman, S. T., \& Wezeman, P. D. 2017. "The state of major arms transfers in 8 graphics". Stockholm: SIPRI. [online] https://www.sipri.org/ 
commentary/blog/2017/state-major-arms-transfers-8-graphics [accessed at 27 October 2019].

CNN. 2019. "Anggaran Pertahanan China Naik Jadi Rp2.500 Triliun”, 5 March 2019 [online] https://www.cnnindonesia.com/internasional/20190305101445-113-374564/ anggaran-pertahanan-china-naik-jadi-rp2500-triliun [accessed at 12 March 2020].

Global Fire Power. 2018. "2018 Vietnam Military Strength” [online] https://www. globalfirepower.com/country-military-strength-detail.asp?country_id=vietnam [accessed at 12 March 2020].

Global Security. 2011. "Vietnam Arms Industry". [online] https://www.globalsecurity. org/military/world/vietnam/industri.htm [accessed at 14 March 2020].

Heiduk, Felix. 2017. “An Arms Race in Southeast Asia? (SWP Research Paper)” [online] https://www.swp-berlin.org/fileadmin/contents/products/research_papers/2017RP10_ hdk.pdf [accessed at 27 October 2019].

Heiduk, Felix. 2018. "Is Southeast Asia really in an arms race?” [online] http://www. eastasiaforum.org/2018/02/21/is-southeast-asia-really-in-an-arms-race/ [accessed at 27 October 2019].

Jennings, Ralph. 2020. "Vietnam Explores Increasing Foreign Military Cooperation to Resist China" VOA, 25 January 2020 [online] https://www.voanews.com/east-asiapacific/vietnam-explores-increasing-foreign-military-cooperation-resist-china [accessed at 14 Maret 2020].

Permanent Court of Arbitration. 2016. "The South China Sea Arbitration” [online] https://pca-cpa.org/wp-content/uploads/sites/175/2016/07/PH-CN-20160712-PressRelease-No-11-English.pdf [accessed at 27 October 2019].

Rajagopalan, Rajeswari. P. 2018. “China's 2018 Military Budget: New Numbers, Old Worries”, The Diplomat, 7 March 2018 [online] https://thediplomat.com/2018/03/ chinas-2018-military-budget-new-numbers-old-worries/ [accessed at 27 October 2019].

RMOL. 2011. "2 Negara ASEAN vs China Lomba Kekuatan Militer”. [online] http:// dunia.rmol.co/read/2011/o6/19/30475/2-Negara-ASEAN-vs-China-Lomba-KekuatanMiliter- [accessed at 28 October 2019].

Strelávina, Daria. 2016. “The battle for Vietnam’s arms market”, Russia Beyond, 6 June 2016 [online] https://www.rbth.com/international/2016/o6/o6/the-battle-forvietnams-arms-market_600449 [accessed at 30 March 2020].

The ASEAN Secretariat. 2016. "Treaty of Amity and Cooperation in Southeast Asia Indonesia, 24 February 1976" [online] http://asean.org/treaty-amity-cooperationsoutheast-asia-indonesia-24-february-1976/\# [accessed at 28 October 2019].

The Economic Times. 2018. "India, Vietnam to step up defence cooperation, oil exploration", 21 November 2018[online] https://economictimes.indiatimes. com/news/defence/india-vietnam-to-step-up-defence-cooperation-oil-exploration/ articleshow/66732922.cms?from $=\mathrm{mdr}$ [accessed at 28 October 2019].

The Maritime Executive. 2018. "China and Vietnam to Settle South China Sea Claims", [online] https://www.maritime-executive.com/article/china-and-vietnam-to-settle- 
The Increase of Vietnam Military Capability in the South China Sea Dispute:

Arms Race or Status Quo?

south-china-sea-claims\#gs.1J32dSQ [accessed at 28 October 2019].

Vietnam Ministry of Defense. 2017. "Vietnam - Defense Sector" [online] https://www. export.gov/article?id=Vietnam-Defense-Sector [accessed at 30 March 2020].

\section{Others}

Market Intelligence Report. 2011. "The Vietnamese Defense Industry”. London.

Wezeman, P. D. Et.al. 2018. "Trend in International Arms Transfer 2017”. SIPRI Fact Sheet March, 7, 235-249. 